\title{
Some Issues Related to the Implementation of the Right to Protection by Individuals in Respect of Whom Criminal Proceedings Are Carried Out to Prove Them Guilty of Committing a Crime
}

\author{
OL'GA P. ALEKSANDROVA \\ Pskov State University, Pskov, Russian Federation \\ ORCID: https://orcid.org/0000-0003-3496-8012, e-mail: pavlovna.76@mail.ru
}

\section{LYUDMILA YU. BUDANOVA}

Pskov Branch of the Academy of the Federal Penitentiary Service of Russia, Pskov, Russian Federation

ORCID: https://orcid.org/0000-0003-1106-9188,e-mail: milabudanovapskov@ mail.ru

\begin{abstract}
Introduction: the article deals with the issues of protection of the rights and freedoms of persons against whom criminal proceedings are carried out to prove them guilty of committing a crime; these issues have always been in the focus of attention of the progressive world community and the legislator. Aims: to analyze the legislation and law enforcement practice of Russia and some other countries in the field of the implementation of the right to protection by persons against whom criminal procedural activities are carried out to prove them guilty of committing a crime, to identify problem issues of a legal nature in this field, and to formulate scientifically substantiated recommendations to address them (minimization). Methods: the dialectical method of scientific knowledge forms the methodological basis of our study. We also use the following methods of scientific cognition: systematic, formal-logical, comparative-legal, etc. Results: the practice of ensuring the right to protection from suspicion or charge, including the decisions of the European Court of Human Rights, shows that not all issues of legal regulation in this area have been resolved to a degree that satisfies science and practice; human rights established by international legal standards are still being violated, the principle of adversarial parties in criminal proceedings is not implemented to the fullest extent, especially in pre-trial proceedings. Discussion: currently, the following issues are debatable: about the possibility of participation of the defender before an official suspicion or charge is brought against the person in an initiated criminal case (from the moment of the beginning of the implementation of procedural actions against a person, aimed at verifying the report of a crime and the involvement of the person in the commission of this crime, before the initiation of a criminal case, as well as from the moment of the implementation of a procedural action in an initiated criminal case affecting the rights and freedoms of the person against whom it is being carried out, and aimed at proving them guilty of committing the crime); about the possible participation of another person as a defender upon the request of the defendant, as well as the scope of the requirements such persons should comply with, and a set of criteria, according to which a decision should be made to allow the individual who does not have the status of defense attorney to act as a defender. Conclusions: based on the results of the study, we formulate proposals for improving the criminal procedure legislation aimed at expanding the scope of possible participation of a defender in criminal proceedings at the stage before the official suspicion or charge is brought, and determining the procedure for considering applications for allowing other persons who do not have the status of defense attorney to act as a defender.
\end{abstract}

Keywords: criminal prosecution; defender; defense attorney; petition.

12.00.09 - Criminal procedure.

For citation: Aleksandrova O.P., Budanova L.Yu. Some issues related to the implementation of the right to protection by individuals in respect of whom criminal proceedings are carried out to prove them guilty of committing a crime. Penitentiary Science, 2021, vol. 15, no. 2 (54), pp. 396-404. DOI 10.46741/2686-9764-2021-15-2-396-404. 


\section{Introduction}

In any country governed by the rule of law, the highest value is the rights and freedoms of man and citizen. Their recognition, observance and protection are the responsibility of the government and its law enforcement agencies. Ensuring the rights and interests of an individual and the protection of persons subjected to criminal prosecution are associated with the problems of implementing the principle of adversarial parties in pre-trial proceedings, ensuring a balance of legal capabilities of the defense and the prosecution, which is in line with the ideas of fair justice [3, pp. 66-67].

Often, the attention of the legislator and processualists is drawn to problematic aspects related to proving the person's guilt in the commission of a crime before the official suspicion or charge is brought against them in the initiated criminal case (from the moment of launch of procedural actions against the person aimed at verifying the report of a crime and the person's involvement in the commission of this crime before the initiation of a criminal case, as well as from the moment of the implementation of a procedural action in the initiated criminal case affecting the rights and freedoms of the person, against whom it is initiated, and aimed at proving them guilty of committing the crime), as well as issues of participation of other persons who do not have the status of defense attorney, as defenders, and the scope of the requirements imposed on the latter.

Thus, in 2013, Article 49 of the Criminal Procedure Code of the Russian Federation was supplemented by Paragraph 6, which provides for the participation of a defense attorney not only from the moment of official suspicion or charge, but from the moment of the launch of procedural actions affecting the rights and freedoms of the person against whom the report of a crime is being checked [12]. In 2017, the RF Criminal Procedure Code was amended to expand the powers of the defender in criminal proceedings [13].

\section{Materials and methods}

The theoretical basis of our research consists of the works of authors who studied the defense in criminal proceedings (A. Belanger [22], B.J. Brock [22], A.V. Endoltseva [9], A.M. Kogamov [23], G.M. Reznik [17], E.V. Skoba [18], J. Temminck Tuinstra [24]), the problems of the participation of the defender in pre-trial proceedings and the term "suspicion" (V.N. Avdeev [1], K.S. Agabekov [2], S.S. Bezrukov [11],
B.B. Bulatov [4], O.A. Voltornist [5], I.O. Voskoboynik [1], A.S. Vrazhnov [6], A.V. Grinenko [7], A.A. Davletov [8], L.M. Duseynova [25], V.V. Nikolyuk [11], I.V. Ovsyannikov [14], S. Tynybekov [25], G.P. Khimicheva [19], O.V. Khimicheva [20], D.V. Sharov [20]), issues of participation of a person who does not have the status of a lawyer as a defender in pre-trial proceedings (S.M. Asmat [21], S.A. Kuzor [15], E.G. Larin [10], Yu.G. Ovchinnikov [15], E.T. Nurmaganbet [21]), etc.

The methodological basis of our study is the dialectical method of scientific cognition. Finding a solution to the research problem was facilitated by the use of the following methods of scientific cognition: system, formal-logical, comparative-legal, etc.

\section{Discussion}

Despite the large number of studies conducted and the steps taken by the legislator to improve the protection of persons against whom the prosecution implements criminal procedural activities to prove them guilty of committing the crime, the practice of ensuring the right to protect persons from suspicion or charge (as well as the practice that takes into consideration the decisions of the European Court of Human Rights), indicates that not all issues of legal regulation in this area have been resolved to a degree that satisfies science and practice.

According to the analysis of the decisions of the European Court of Human Rights, we see that complaints about violations of Article 6 of the Convention for the Protection of Human Rights and Fundamental Freedoms of November 4, 1950, which established the right to defend oneself personally or through the representation of a defender, are not uncommon among complaints against the Russian Federation; and the ECHR finds violations of international law and concludes the consideration of such complaints with a decision on the award of monetary compensation. Thus, the ECHR revealed violations related to the failure to ensure the right to use the help of a defender or the late provision of this right (ECHR decision of March 26, 2015 in the case "Volkov and Adamskiy v. the Russian Federation" (complaints no. 761409 and 30863/10); ECHR decision of October 6, 2015 in the case "Turbylev v. the Russian Federation" (complaint no. 472209); ECHR decision of December 11, 2018 in the case "Rodionov v. the Russian Federation" (complaint no. 9106/09)). 


\section{Reasoning}

Fundamental human rights and freedoms are recognized and protected by international legal acts. The vast majority of legal norms contained in international regulations (Articles 7 and 11 of the Universal Declaration of Human Rights, adopted by the UN General Assembly on December 10, 1948; Articles 2 and 14 of the International Covenant on Civil and Political Rights (ICCPR) adopted by the UN General Assembly Resolution 2200A (XXI) on December 16, 1966; Article 6 of the Convention for the Protection of Human Rights and Fundamental Freedoms adopted on November 4, 1950; Basic Principles on the Role of Lawyers adopted by the Eighth United Nations Congress on the Prevention of Crime and the Treatment of Offenders, Havana, Cuba August 27 to September 7, 1990) are aimed at protecting and ensuring the rights, freedoms and legitimate interests of the individual, especially in criminal proceedings initiated against them.

International standards in the field of protection from criminal prosecution have also been implemented in the criminal procedure legislation of many countries, including the countries of the Commonwealth of Independent States.

For example, the criminal procedure codes of the Russian Federation (CPC RF), the Republic of Kazakhstan (CPC RK), the Republic of Belarus (CPC RB), the Republic of Uzbekistan (CPC RU), the Republic of Moldova (CPCRM) contain norms and principles on ensuring the right to protection (Article 16 of CPC RF, Article 26 of CPC RK, Article 17 of CPC RB, Article 24 of CPC RU, Article 17 of CPC RM). These articles deal with ensuring the right to protection of persons who have an official status of suspect or defendant, and they can exercise this right both personally and with the help of a defender. At the same time, in the norms of the codes of Kazakhstan and Moldova, the list of participants in the process, who are guaranteed the right to defense, is not limited to suspects and defendants.

Thus, according to Article 26 of the Criminal Procedure Code of the Republic of Kazakhstan, a witness also has the right to defense, if in the application and report on a criminal offense he/ she is indicated as the person who committed this offense, or a witness participating in the criminal process testifies against him/her, but he/she is not subjected to procedural detention or a decision is not made to recognize him/her as a suspect.

In accordance with Article 17 of the Criminal Procedure Code of the Republic of Moldova, during the entire criminal proceedings, the parties (suspect, accused, defendant, victim, civil plaintiff, civil defendant) have the right to use the assistance of a defender or to be represented by a defender of their choice or a defense attorney who provides legal assistance guaranteed by the state.

In addition, we should note that the criminal procedure codes of Kazakhstan and Belarus provide a broader concept of criminal prosecution that meets international standards, in contrast with CPC RF. Thus, in accordance with Paragraph 22 of Article 7 of CPC RK, criminal prosecution is a procedural activity carried out by the prosecution in order to establish an act prohibited by criminal law, the person who committed it and the guilt of the latter in committing the criminal offense, as well as to ensure the application of punishment or other measures of criminal legal impact to such a person. A similar definition is contained in Paragraph 48 of Article 6 of CPC RB.

According to paragraph 55 of Article 5 of CPC RF, criminal prosecution is understood as a procedural activity carried out by the prosecution in order to prove the guilt of a suspect accused of committing a crime.

Article 16 of CPC RF, which contains the norms and principles of criminal procedure, points out that the suspect and the defendant are provided with the right to defense, which they can exercise personally or with the help of a defender and (or) a legal representative, and Part 1 of Article 49 of CPC RF defines a defender as a person who protects the rights and interests of suspects and defendants in accordance with the procedure established by CPC $\mathrm{RF}$ and provides them with legal assistance in criminal proceedings.

Taking into account the norms mentioned above, the Russian legislator associates the participation of a defender in a criminal case with the presence of an official suspicion or charge in the initiated criminal case, which is reflected in the procedural document established by law, that is, with the implementation of criminal prosecution. However, Paragraph 6 of Part 3 of Article 49 of CPC RF provides for the possibility of participation of a defender from the moment when procedural actions were launched, affecting the rights and freedoms of a person against whom a report of a crime is being checked, that is, when there is no criminal case yet and criminal prosecution under Paragraph 55 of Article 5 of CPC RF is not carried out yet. 
The above norm does not correspond to the provisions of Part 1.1 of Article 144 of CPC RF that provide an opportunity to use the services of a lawyer for a person participating in procedural actions when a report on a crime is being checked before the initiation of a criminal case; accordingly, this person does not have the procedural status of suspect or defendant, taking into account the provisions of Articles 46 and 47 of CPC RF. That is, here we are not talking about a defense attorney, but a lawyer who represents the interests of a person participating in procedural actions before the initiation of a criminal case, and who providing legal assistance to them.

In addition, CPC RF distinguishes between the terms "defense attorney" and "defender", provides for the possibility of participation of one of the close relatives of the defendant or another person, whose participation is requested by the defendant (Part 1 of Article 49) as a defender along with the defense attorney, according to the court decision (instead of a lawyer if the case is considered by a justice of the peace), establishes the right of the suspect and defendant to use the assistance of a defender, including assistance provided on a free-ofcharge basis (Article 16, Paragraph 3 of Part 4 of Article 46, Paragraph 8 of Part 4 of Article 47).

A reasonable question arises concerning the possibility of participation of the defender until the official suspicion or charge is raised, which would be reflected in the documents provided for by the criminal procedure legislation. Here we consider it useful to refer to the practice of the European Court of Human Rights, as well as the higher courts of the Russian Federation.

The European Court of Human Rights considers the concept of a "criminal charge" as having an "autonomous" meaning, independent of the categorizations employed by the national legal systems. The European Court of Human Rights understands the charge (in the sense provided for in Article 6 of the Convention for the Protection of Human Rights and Fundamental Freedoms) as not only the official notification of the charge, but also as other measures related to the suspicion of committing a crime that entail serious consequences or significantly affect the situation of the suspect (the judgment of February 27, 1980 in the case of Deweer v. Belgium; the judgment of July 15, 1982 in the case of Eckle v. Germany the judgment of December 10, 1982 in the case of Foti and Others v. Italy), that is, the ECHR considers it necessary to apply a substantive, rather than a formal approach.

A classic example in this regard is the judgment in the case of Deweer v. Belgium, which states that the Court should be inclined to prefer a "substantive", rather than a "formal", conception of the "charge" and is compelled to look behind the appearances and investigate the realities of the procedure in question. Further, the notion of "charge" is defined by the ECHR as the official notification given to an individual by the competent authority of an allegation that he has committed a criminal offence, which substantially affected the situation of the suspect.

Thus, the ECHR understands the accused (suspects) as not only those persons who are formally charged or who are formally recognized as accused or as suspects, but also those against whom any actions are taken that imply such suspicion and can seriously affect the situation of this person.

Back in 2000, the Constitutional Court of the Russian Federation attempted to expand the definitions of the terms "suspicion" and "charge". In its resolution no. 11-P of June 27, 2000 , it pointed out that for the purpose of exercising the constitutional right to the assistance of a lawyer (defender), it is necessary to take into account not only the formal procedural, but also the actual situation of the person against whom a public criminal prosecution is being carried out. At the same time, the fact of criminal prosecution and, consequently, the accusatory activity directed against a particular person may be confirmed by the fact of conducting investigative actions search, identification, interrogation, etc.) against them, and other measures taken to expose them or indicate the existence of suspicions against them (in particular, an explanation in accordance with Part 1 of Article 51 of the Constitution of the Russian Federation of the right not to testify against oneself). Since such actions are aimed at identifying the facts and circumstances incriminating the person against whom the criminal prosecution is being conducted, he/she should be immediately given the opportunity to seek the help of a lawyer (defender). This ensures conditions that allow this person to get a proper understanding of their rights and obligations, the charges against them and, consequently, to defend themselves effectively, and prevent further recognition of the evidence obtained during the investigation as inadmissible (Part 2 of Article 50 of the Constitution of the Russian Federation). 
This position is reflected in further decisions of the Supreme Court of the Russian Federation and the Constitutional Court of the Russian Federation, where the concepts of "criminal prosecution" and "charge" are interpreted more broadly than in the Criminal Procedure Code of the Russian Federation.

Thus, the resolution of the Plenum of the Supreme Court of the Russian Federation no. 29 of June 30, 2015 states that ensuring the right to defense is one of the principles of criminal proceedings at all its stages, and in accordance with it, the right to defense is held by a person in respect of whom procedural actions affecting their rights and freedoms are carried out to verify the report of a crime in accordance with the procedure provided for in Article 144 of CPC RF, as well as any other person whose rights and freedoms are significantly affected or may be significantly affected by actions and measures that indicate an accusatory activity directed against them, regardless of the formal procedural status of such a person.

According to the resolution of the Plenum of the Supreme Court of the Russian Federation no. 11 of March 29, 2016 and the resolution of the Constitutional Court of the Russian Federation no. 23-P of June 13, 2019, criminal prosecution is understood as the adoption of one of the procedural decisions specified in Part 1 of Article 46 or Part 1 of Article 47 of CPC RF, according to which an individual is recognized as a suspect or defendant, or the moment when one of the procedural actions was initiated against the person in accordance with Part 1.1 of Article 144 of CPC RF, or investigative actions aimed at proving their guilt in the commission of the crime, while these actions precede the recognition of this person as a suspect or defendant.

G.P. Khimicheva, O.V. Khimicheva, and D.V. Sharov point out that the notion of "suspect" is gradually being blurred [19] and currently implies not only the person against whom official suspicion has been raised and criminal prosecution is being carried out, but also any other person who is actually being prosecuted for committing a crime and is exposed in this [20].

According to V.N. Avdeev and I.O. Voskoboynikov, the lawyer who participates in the stage of checking the report of the crime, acquires the procedural status due to the actual situation of their client and the procedural function the lawyer performs, being in some cases the representative, in others - the defender [1].

B.B. Bulatov comes to the conclusion that the modern reality is on the way to extending the right to protection from actually ongoing prosecution to persons who are not in the relevant procedural position yet [4, p. 4].

In view of the above, we consider it necessary to adjust the notion of "defender" in national legislation and to reflect the possibility of their participation not only from the moment of raising an official suspicion or charge, but also from the moment of carrying out a procedural action affecting the rights and freedoms of the person against whom it is being carried out, and aimed at exposing the latter in the commission of a crime.

Many disputes among the processualists are caused by the regulation allowing a close relative or other person, whose admission is requested by the defendant, to participate as a defender; moreover, there still exist unresolved issues concerning the scope of the requirements imposed on such persons, the criteria, according to which the court decides to allow a person who does not have the status of attorney to act as a defender.

In adopting the Basic Principles on the Role of Lawyers, the Eighth United Nations Congress on the Prevention of Crime and the Treatment of Offenders specifically emphasized that these principles also apply, if necessary, to persons who perform the functions of lawyers without having an official status as such.

The criminal procedure laws of Kazakhstan, Belarus, and Uzbekistan provide for the possibility of admitting close relatives as defenders along with a lawyer (Part 2 of Article 66 of CPC RK, Part 3 of Article 44 of CPC RB, and Article 49 of CPC RU).

Besides, in accordance with Articles 42 and 44 of CPC RU, public defenders sent by nongovernmental associations and collectives can participate in court proceedings.

According to Article 47 of CPC RM, other persons can act as a defender, if they are granted the powers of a defender by law from the moment of assuming the obligation to protect the interests of the person in the case and with their consent.

In accordance with Part 2 of Article 49 of CPC RF, defense in criminal proceedings can be carried out not only by an attorney, but also by one of the close relatives of the defendant, as well as by another person for whose admission the defendant applies, but such participation is possible only along with a defense attorney (during the proceedings with a justice of the peace, the specified person can be admitted instead of a lawyer). The participation of a close 
relative or other person is possible by a court decision.

This provision of the law has an ambiguous interpretation and contains a number of controversial points.

According to Part 1 of Article 48 of the Constitution of the Russian Federation, everyone is guaranteed the right to receive qualified legal assistance. Part 2 of this rule establishes the right to use the assistance of a lawyer (defender) from the moment of apprehension, detention or arraignment. We would like to draw attention to the fact that the wording contains two terms: a lawyer and a defender. Thus, the Basic Law does not prohibit a person who does not have the status of a lawyer from providing legal assistance.

The legislation does not contain a clear definition of the term "qualified legal assistance", therefore, and perhaps for fear of contradictions between Part 1 of Article 48 of the Constitution of the Russian Federation and Part 2 of Article 49 of CPC RF, the legislator provided that other persons and close relatives can participate in criminal proceedings as defenders only along with a lawyer, because not in every case another person or a close relative has a set of qualities that correspond to the term "qualified legal assistance".

E.M. Ametistov, a judge of the Constitutional Court of the Russian Federation, points out that the guarantee of obtaining qualified legal assistance is a constitutional obligation of the state to provide everyone with a sufficiently high level of legal assistance, but this does not imply the obligation of a citizen to use only this level of assistance, unless, of course, the constitutional principles of legal proceedings, as well as the rights and interests of other persons, are violated [16].

The Criminal Procedure Code of the RSFSR of 1960, before Federal Law 73-FZ of June 15, 1996 amended it, in addition to lawyers, allowed representatives of trade unions and other non-governmental organizations to act as defenders in cases involving members of these organizations, as well as other persons in cases provided for by law. However, after the above-mentioned changes came into force, lawyers and representatives of trade unions or other non-governmental associations were allowed to act as defenders. Close relatives, legal representatives of the defendant, and other persons were admitted by a court order or a judge's order.

It is important to note that in accordance with Part 2 of Article 49 of CPC RF, the participation of close relatives and other persons is possible only along with a lawyer, except in cases of criminal proceedings before a justice of the peace, while the Criminal Procedure Code of the RSFSR of 1960 provided for the possibility of their independent participation in criminal proceedings.

Modern law enforcement practice develops in such a way that in pre-trial proceedings, as a rule, the function of defender is performed by a lawyer, and the participation of another person is extremely rare.

However, the defendant may perceive the defender as not just a lawyer: sometimes psychological assistance, as well as moral support, which do not depend on the monetary payment for the provision of services, are more important for the defendant. In addition, the quality of protection, for example, by a person who has an economic education, in the cases of an economic orientation, in some sense, may be higher than with the participation of a person with a legal education. The involvement of such persons in the defense can significantly strengthen it, and the participation of persons who do not seek monetary remuneration is also important for the case.

In 1997, the Constitutional Court of the Russian Federation examined the constitutionality of the provisions of the Criminal Procedure Code of the RSFSR, according to which only lawyers and representatives of trade unions and other non-governmental associations could participate as defenders in criminal proceedings (Part 4 of Article 47 of the Criminal Procedure Code of the RSFSR). The applicants, who were in the status of defendants, wanted to involve legal experts who did not have the status of a lawyer as defenders during the preliminary investigation; the investigators who carried out criminal proceedings did not allow it, arguing that the participation of such persons was not provided for by law. The court and the prosecutor's office recognized the opinion of the bodies that carried out the preliminary investigation as legitimate. The Constitutional Court of the Russian Federation, in its decision no. 2-P of January 28,1997 , stated that the content of the right to choose a lawyer (defender) does not mean the right to choose as a defender any person at the discretion of the suspect or defendant and does not imply the possibility of participation of any person as a defender in the criminal process. The participation of any person of the suspect's or the defendant's choice as a defender during the preliminary investigation 
may lead to the fact that the defender will be a person who does not possess the necessary professional skills, which is incompatible with the tasks of justice and the state's obligation to guarantee everyone qualified legal assistance.

A separate opinion was expressed by four judges of the Constitutional Court of the Russian Federation who participated in the consideration of these complaints.

Judge V.O. Luchin recognized that the provisions of Part 4 of Article 47 of the Criminal Procedure Code of the RSFSR restrict the right of suspects and defendants to use qualified legal assistance from persons who are not members of bar associations, and do not comply with the Constitution of the Russian Federation.

Judge E.M. Ametistov stressed that the admission of legal experts who do not have the status of lawyers to the defense of suspects and defendants does not contradict defense goals. Taking into account the position of the legislator, which allows persons, who are not required to confirm their qualifications, to act as defenders, and even allows the defendant to decline the services of a defender and defend themselves on their own, this also does not contradict the principles of legal proceedings, established in Part 3 of Article 123 of the Constitution of the Russian Federation.

The dissenting opinions of judges N.T. Vedernikov and V.I. Oleynik also confirm that the admission of a person who does not have the status of a lawyer to participate in the defense does not reduce the quality of the defense.

In addition, the above-mentioned international legal acts do not restrict the right of a suspect or defendant to choose a defender, including another person who does not have the status of a lawyer.

In view of the above, we think that the admission of close relatives and other persons as defenders along with the lawyer at the request of the defendant is very justified from the point of view of strengthening the defense, but the legislation does not clearly establish the procedures for such admission, as well as the requirements for these persons, which in practice gives rise to certain issues.

\section{Conclusion}

The analysis of international standards, norms of the criminal procedure legislation of Russia and some other countries in the field of ensuring the right to protection from criminal prosecution allowed us to formulate proposals for improving the institution of defense.
In order to expand the possibilities of using the assistance of a defender and strengthen the adversarial nature of the parties at the pretrial stages of the criminal process, we find it appropriate to make the following changes to the Criminal Procedure Code of the Russian Federation:

1. To supplement Part 1 of Article 49 with the term "defender" in the following wording: "A defender is a person who, in accordance with the procedure established by the present Code, protects the rights and interests of suspects and defendants, as well as persons against whom procedural actions have been initiated during the verification of a report on a crime affecting their rights and freedoms, or persons against whom investigative actions have been initiated that are aimed at proving them guilty of committing a crime and that precede their recognition as suspects or defendants, and who provides them with legal assistance".

2. In Part 3 of Article 49, to replace the words "in a criminal case" with the words "in criminal proceedings".

3. To amend Item 6 of Part 3 of Article 49 of the Code to read as follows: "6) since the beginning of the procedural action that affects the rights and freedoms of the person in respect of whom the message about the crime is being checked in the manner prescribed by Article 144 of this Code, or since the beginning of the investigative action aimed at proving the person guilty of committing a crime".

4. To supplement the Criminal Procedure Code of the Russian Federation with Article 49.1 "Procedure for considering the application of the accused or defendant for admission of a close relative or other person as a defender in criminal proceedings" in the following wording:

"1. Admission of one of the close relatives or another person as a defender along with the lawyer is carried out at the request of the defendant or suspect by the interrogating officer, the investigator or the court before which the criminal case is pending.

2. The application of the defendant or suspect for admission of one of the close relatives or another person as a defender along with the lawyer shall be considered within the time limits established by Article 121 of the present Code.

3 . When considering and granting the application for admission of one of the close relatives or another person as a defender along with the lawyer, the investigator, the inquirer and the court must take into account the possibility of participation of such a defender in the case, the 
presence or absence of obstacles provided for in Article 72 of the Criminal Procedure Code of the Russian Federation, as well as other possible obstacles to the participation of such a defender in the criminal process, including the state of health, age, employment in the main job, education, legal capacity of such a person, and others.

4. The inquirer, the investigator, the judge shall make a decision on the satisfaction of the application for admission of one of the close relatives or another person as a defender along with the lawyer or on the refusal to satisfy it, and the court shall make a ruling that is brought to the attention of the person who filed the application.

5. The following persons may not participate as a defender along with a defense attorney:

1) persons under the age of 18;

2) persons recognized by the court as incapable or whose legal capacity is limited by the court:

3) persons registered with a narcological or neuropsychiatric dispensary in connection with treatment for alcoholism, drug addiction, substance abuse, chronic and prolonged mental disorders;

4) persons suspected or accused of committing crimes, convicted persons;

5) persons who do not speak the language in which the criminal proceedings are conducted;

6) persons with physical or mental disabilities that prevent full participation in criminal proceedings.

6. The decision on the application may be appealed in accordance with the procedure established by Chapter 16 of the present Code".

The above recommendations are aimed at improving the institution of protection from criminal prosecution, strengthening the adversarial nature of the parties in pre-trial proceedings and implementing the purpose of criminal proceedings, which consists not only in protecting individuals and organizations who have suffered from crimes, but also in protecting individuals from illegal and unfounded accusations, convictions, and restrictions on their rights and freedoms.

\section{REFERENCES}

1. Avdeev V.N., Voskoboynik I.O. On participation of defense counsel in course of receipt of explanations and performance of other procedural actions at participation of person notification of whose crime is verified. Advokatskaya praktika=Advocate's Practice, 2017, no. 3, pp. 32-37. (In Russ.).

2. Agabekov K.S. On the beginning of criminal prosecution in the conditions of protective justice. Mirovoi sud'ya=Justice of the Peace, 2019, no. 1, pp. 14-18. (In Russ.).

3. Baeva N.A. International legal and constitutional standards for the protection of citizens' rights and interests in criminal proceedings. Sudebnaya vlast' i ugolovnyi protsess=Judicial Authority and Criminal Process, 2018, no. 4, pp. 60-67. (In Russ.).

4. Bulatov B.B. Protsessual'noe polozhenie lits, v otnoshenii kotorykh osushchestvlyaetsya obvinitel'naya deyatel'nost': avtoreferat dissertatsii na soiskanie uchenoi stepeni kandidata yuridicheskikh nauk [Procedural position of the persons subject of the indictment activity: Candidate of Sciences (Law) dissertation abstract]. Omsk, 2011. 26 p.

5. Voltornist O.A. Issues of exercising the right to defense amid the explanations of the Plenum of the Supreme Court of the Russian Federation. Vestnik Omskoi yuridicheskoi akademii=Siberian Law Review, 2016, no. 2, pp. 56-59. (In Russ.). 6. Vrazhnov A.S. Challenging situations for an attorney for the defense on criminal case initiation and preliminary investigation stages. Advokatskaya praktika=Advocate's Practice, 2019, no. 2, pp. 31-34. (In Russ.).

7. Grinenko A.V. Parity of rights of parties in pre-trial criminal procedure. Advokatskaya praktika=Advocate's Practice, 2017, no. 4, pp. 35-40. (In Russ.).

8. Davletov A.A. The problem of defining a status of criminally prosecuted person in the stage of institution of a criminal case. Rossiiskii yuridicheskii zhurnal=Russian Juridical Journal, 2015, no. 4, pp. 61-67. (In Russ.).

9. Endol'tseva A.V. Exercising of the constitutional right to receive qualified legal assistance in Russian criminal proceedings. Ugolovnoe sudoproizvodstvo=Criminal Judicial Proceeding, 2019, no. 4, pp. 25-30. (In Russ.).

10. Larin E.G. Admission of a person who is not a lawyer as a defender at the stage of preliminary investigation: legislation and practice. Zakonodatel'stvo i praktika=Legislation and Practice, 2010, no. 2, pp. 21-24. (In Russ.).

11. Nikolyuk V.V., Bezrukov S. S. Conceptual and applied issues related to the resolution of the Plenum of the Supreme Court of the Russian Federation on the application of the norms on the right to protection. Ugolovnyi protsess=Criminal Process, 2015, no. 8, pp. 26-33. (In Russ.).

12. On amendments to Articles 62 and 303 of the Criminal Code of the Russian Federation and the Criminal Procedure Code of the Russian Federation: Federal Law 23-FZ of March 4, 2013. In: Sobranie zakonodatel'stva Rossiiskoi Federatsii [Collection of Legislation of the Russian Federation]. 2013. No. 9. Article 875. (In Russ.).

13. On amendments to the Criminal Procedure Code of the Russian Federation: Federal Law 73-FZ of April 17, 2017. In: Sobranie zakonodatel'stva Rossiiskoi Federatsii [Collection of Legislation of the Russian Federation]. 2017. No. 17. Article 2455. (In Russ.).

14. Ovsyannikov I.V. Actions and decisions taken at the initial stage of pre-trial proceedings to be legal as well. Zakonnost'=Legality, 2017, no. 4, pp. 45-49. (In Russ.).

15. Ovchinnikov Yu.G., Kuzora S.A. Problems of participation of the "other" person as a defender in the pre-trial stages of criminal proceedings Rossiiskaya yustitsiya=Russian Justice, 2014, no. 11, pp. 43-44. (In Russ.).

16. In the case of checking the constitutionality of Part Four of Article 47 of the Criminal Procedure Code of the RSFSR in connection with the complaints of citizens B.V. Antipov, R.L. Gitis and S.V. Abramov: Resolution of the Constitutional Court 
of the Russian Federation of January 28, 1997 no. 2-P. In: Sobranie zakonodatel'stva Rossiiskoi Federatsii [Collection of Legislation of the Russian Federation]. 1997. No. 7. Article 871. (In Russ.).

17. Reznik G.M. To the issue concerning the constitutional content of the term "qualified legal assistance". Advokat=Lawyer, 2007, no. 4, pp. 25-27. (In Russ.).

18. Skoba E.V. Realizatsiya konstitutsionnogo prava na kvalifitsirovannuyu yuridicheskuyu pomoshch' $v$ dosudebnom proizvodstve po ugolovnym delam: avtoreferat dissertatsii na soiskanie uchenoi stepeni kandidata yuridicheskikh nauk [Implementation of the constitutional right to qualified legal assistance in pre-trial proceedings in criminal cases: Candidate of Sciences (Law) dissertation abstract]. Moscow, 2010. 28 p.

19. Khimicheva G.P. On the issue of correcting the principle of presumption of innocence. Vestnik ekonomicheskoi bezopasnosti=Bulletin of Economic Security, 2016, no. 5, pp. 83-86. (In Russ.).

20. Khimicheva O.V., Sharov D.V. Some aspects of ensuring the rights of a person when detained on suspicion of committing a crime. Zakony Rossii: opyt, analiz, praktika=Laws of Russia: Experience, Analysis, Practice, 2018, no. 5, pp. 56-61. (In Russ.).

21. Asmat S.M., Nurmaganbet E.T. Provision of qualified legal aid defence counsel to the suspect and accused persons. Bulletin d'EUROTALENT-FIDJIP, 2015, no 8, pp. 66-70.

22. Belanger A., Brock B.J. The practice of criminal defence: Why we fight and defend those most imperilled, every day. International Journal of Public Law and Policy, 2012, vol. 2, no. 4, pp. 352-356.

23. Kogamov A.M. Juridical personality of a defense lawyer in the context of international contractual and other obligations of the republic of Kazakhstan in criminal practice. World Applied Sciences Journal, 2013, vol. 26, no. 8, pp. 1094-1099.

24. Temminck Tuinstra J.P.W. Assisting an accused to represent himself: appointment of amici curiae as the most appropriate option. Journal of International Criminal Justice, 2006, vol. 4, no. 1, pp. 47-63.

25. Tynybekov S., Nurmaganbet E.T., Duysenova L.M. The concept, value, and the procedural position of defense attorney at the preliminary investigation. Life Science Journal, 2014, vol. 11, special issue 5, pp. 239-247.

\section{INFORMATION ABOUT THE AUTHORS}

OL'GA P. ALEKSANDROVA - Candidate of Sciences (Law), Associate Professor, associate professor at the Department of Law Enforcement Activity, Criminal Law and Process, Pskov State University, Pskov, Russian Federation. ORCID: https:// orcid.org/0000-0003-3496-8012, e-mail: pavlovna.76@mail.ru

LYUDMILA YU. BUDANOVA - Candidate of Sciences (Law), associate professor at the Department of Regime and Intelligence-Gathering Activities in the Penal System, Pskov Branch of the Academy of the Federal Penitentiary Service of Russia, Pskov, Russian Federation. ORCID: https://orcid.org/0000-0003-1106-9188, e-mail: milabudanovapskov@mail.ru

Received March 21, 2021 